\title{
Cognitive \& Pragmatic Aspects of Polycodedness of a Scientific Text, A Case Study of the Spanish Language
}

\author{
Svetlana Vladimirovna Dmitrichenkova (Corresponding author) \\ Peoples' Friendship University of Russia, Russia \\ E-mail: svetlana.v.dmitrichenkova@mail.ru \\ Elena Anatolyevna Dolzhich \\ Peoples' Friendship University of Russia, Russia \\ Taisia Georgievna Popova \\ Peoples' Friendship University of Russia, Russia
}

\author{
Received: 29-06-2016 \\ Accepted: 09-09-2016 \\ Advance Access Published: November 2016 \\ Published: 02-01-2017 \\ doi:10.7575/aiac.ijalel.v.6n.1p.128 \\ URL: http://dx.doi.org/10.7575/aiac.ijalel.v.6n.1p.128
}

\begin{abstract}
The aim of this study is to investigate the polycodedness of a Spanish scientific text as a result of interaction between codes of different semiotic systems and discourses. A polycode text focuses the fact of interaction of different codes, i.e. symbols, systems of symbols, signs and rules of their combinations with each other for the transmission, processing and storage of information in the form most adapted thereto. This term describes the phenomenon of textual heterogeneity at the level of form achieved through a mix of different semiotic systems, such as verbal and visual. In this sense, the phenomenon of polycodedness is directly related to the manifestations of interdiscursiveness. A particular attention is given to the synthesis of verbal and non-verbal means of communication, the consideration of polycode scientific texts in terms of their constituent cognitive structures that help to identify the essential properties of scientific text. The discursive and communicative approaches, being the leaders within the modern linguistics, comprise the methodological base of the research. At each stage of work, the methods that best meet the goals and objectives of the research were involved. Such methods include a discourse analysis, a method of classification and systematization, a method of quantitative analysis followed by a qualitative interpretation of the data. The emergence of a semiotically complicated text, in which the author's intention is realized simultaneously using both a verbal code and a variety of non-verbal means, is an evidence of major changes in the modes of transmitting information about the world. The material study is based on research papers and dissertations in Spanish on various branches of scientific knowledge defended at the Autonomous University of Madrid (Spain).
\end{abstract}

Keywords: scientific text, discourse, polycodedness, verbal, non-verbal means

\section{Introduction}

The scientific discourse is of undoubted interest for a special linguistic analysis because of the special role that science plays in the modern world. Currently, in most cases, the text is seen as a particular aspect of a broader phenomenon discourse, and is studied by the discipline called "discursive analysis". Studying the theoretical foundations of the discourse revealed that the term "discourse" began to be widely used in the early 1970s in the meaning close to that, in which the term "functional style" was common in Russian linguistics.

An interest to studying general discourse and its specificity is reflected in a variety of domestic and foreign publications, such as (Baranov, 1993; Borbotko, 1998; Demyankov, 2001; Dridze, 1984; Karasik, 2000; Kibrik, 1994; Kubryakova, 1997; Makarov, 2003; Mikhaylova, 1999; Popova, 2003; Slyshkin, 2000; Sternin, 2000; Tsurikova, 2002; Chernyavskaya, 2006, 2009; Shakhovskiy, 1998; Dijk, 2000; Link, 1990; Sager, 1997, etc.).

The original meaning of the word discourse is the "rational thinking" from the Latin "discursus", which after a certain rethinking transformed into the meaning of a "dialogue". It should be noted that the terms "discourse" and "text" were virtually synonymous until the 1970 s.

However, in the late 1970s - early 1980s, there were tendencies for their disengagement from the gradual differentiation of the concepts of "text" and "discourse." The term "text" is now understood as an abstract, formal structure, and "discourse" - as a different kind of its actualization, viewed from the standpoint of the mental processes and in connection with extra-linguistic factors. The concept of discourse can be seen in some contexts, referred to in the works by a well-known researcher T. van Dijk (Dijk, 1994): 
- Discourse in the broad sense. Discourse is a communicative event that occurs between the speaker, the listener (the observer, etc.) during the process of communicative action in a certain timed, spatial and other context. This communicative action can be oral, written, have verbal and nonverbal components.

- Discourse in the narrow sense is a written or oral verbal product of communicative action (a text or a conversation).

- "Discourse" is a relevantly uttered text, and "text" is an abstract grammatical structure of the uttered (speech | language).

- Discourse as a specific conversation. Using the concept of "discourse" always concerns some specific objects in a particular situation and in a particular context, "this discourse", "his discourse", "these discourses".

- Discourse as a type of conversation. The concept of "discourse" is used in this sense and can deal not with the specific communicative actions, but with the types of verbal production.

- Discourse as a genre. The concept of "discourse" is used to refer to a particular genre, such as "news discourse", "political discourse", "scientific discourse", and others.

As Chernyavskaya notes, discourse should be understood as texts in close connection with the situational context: in conjunction with the social, cultural, historical, ideological, psychological and other factors, with the system of communicative-pragmatic and cognitive target settings of author that interacts with the target determination of a specific ordering of linguistic units of different levels at implementing within the text. Discourse characterizes the communicative process leading to the formation of a certain formal structure that is the text (Chernyavskaya, 2009).

Scientific discourse is the result of a special kind of dialogic interaction, combining elements of scientific argument and informative dialogue, the participants of which are either real voice actors (scientists), or scientific texts, in which the thoughts and ideas of the participants are implemented.

Scientific discourse is a collection of scientific works as a result of the interaction between the author's intentions, the possible reader's reactions and the text that displays the work within the general cognitive space. Cognitive interdiscursiveness category reflects the interaction of the various systems of knowledge, cultural codes and cognitive strategies.

Yu.M. Lotman stresses that the text created by the author is included in the complex system of non-textual links, which create a complex code that allows to decode the information contained in the text. A complication of the structure of the text objects of different coding allows that the reader more accurately decodes the information (Lotman, 1999).

A polycode text is a special form of textual heterogeneity. Scientific text as a communicative value is not limited to language component. It includes various elements significantly affecting its overall perception. Thus, in conjunction with other signs of nature, verbal signs most successfully realize their communicative functions.

Specialists from various fields of linguistics addressed the description of non-verbal means of communication, their functioning in speech and writing. The research results are presented particularly in the works by E.E. Anisimova, A.G. Baranov, L.M. Bolshiyanova, M.B. Voroshilova, S.S. Danilyuk, I E. Klyukanov, G.V. Kolshanskiy, V.I. Mikhalkovich, A.V. Mikheyev, O.V. Mishina, T.M. Nikolaeva, L.B. Parshin, N.V. Petrovskiy, S.P. Popov, N.V. Rekonvald, A.A. Reformatskiy, A.G. Sonin, Yu.A. Sorokin, N.V. Stepanyuk, E.F. Tarasov, B.A. Uspenskiy, N.I. Khristoforova, T.V. Yakhontova, and T. Miller. These linguists paid much attention to the texts of almost all functional styles.

For example, L.M. Bolshiyanova (Bolshiyanova, 1987) in her article "The external organization of a newspaper text of a polycode nature" examines the functioning of non-verbal communication in newspaper articles. The dissertation by N.V. Stepanyuk (Stepanyuk, 2002) is devoted to the methods for integrating messages of different codes into literary and scientific text. A.G. Sonin (Sonin, 2005), in turn, explores the cognitive aspect of the polycode texts. M.B. Voroshilov (Voroshilov, 2007) analyzes a semiotically complicated text in political discourse. S.S. Bychkov (Bychkov, 2013) explores the polycodedness as a macrostructural sign of printed texts.

Psycholinguists Yu.A. Sorokin and E.F. Tarasov (Sorokin, \& Tarasov, 1990) introduced the term "creolized texts". It is a "text, texture consisting of two non-homogeneous parts: verbal (language/speech) and non-verbal, belonging to other sign systems rather than natural language."

A.A. Bernatskaya (Bernatskaya, 2000, p. 109) considers creolization as "a combination of different semiotic systems in a complex that meets the condition of textuality."

E.E. Anisimova, in turn, supplemented this definition having distinguished that "in relation to the written communication, the creolized texts include the texts, the dominant of the paralinguistic means field of which is formed by the iconic (pictorial) means" (Anisimova, 2003, p. 8). According to the above-mentioned research, a creolized text is characterized by the obligatory presence of a visual (iconic) element in its structure, which is integrated into a verbal message in the meaningful, content-compositional, and conceptual-linguistic aspects.

Functioning in the same semantic space, interacting with each other, verbal and iconic components of the message to ensure the integrity and coherence of the text creolized its communicative effect.

However, as rightly pointed by V.E. Chernyavskaya (Chernyavskaya, 2009, 2016), the term "creolized text" itself used to refer the mixed texts with linguistic and non-linguistic components is not straightforward, as the Creole languages are characterized as representing a combination of a dictionary of the language with the grammar of another. More 
precisely, the essence of the phenomenon in question sends the term a "polycode text" that secures the interaction of different codes - systems of symbols, symbols, signs, rules of their combination with each other for the transmission, processing and storage of information in the most adapted to this form.

The polycodedness is a manifestation of the heterogeneity of the text due to the synthesis of different semiotic systems, for example, both verbal and visual. In this sense, the phenomenon is directly related to the manifestations of polycodedness, interdiscursiveness, the interaction of different discourses.

Currently, in the area of attention of scientists are such varieties of a polycode text, ad text, comics, news text, teletext, as well as radio and hypertext. Unfortunately, there are virtually no studies looking at scientific text within a cognitive paradigm.

Studying the polycode texts in terms of their constituent cognitive structures on the scientific material of texts virtually been taken. Meanwhile, the study of scientific texts in the framework of the cognitive paradigm is particularly relevant. The cognitive approach helps to identify the essential properties of scientific text, remaining unnoticed when considered in the framework of other scientific paradigms. Most researchers recognize that "for an explanation of the cognitive paradigm defined explication relations with the structures of linguistic expression of knowledge and the procedures of their treatment" (Baranov, \& Dobrovolsky, 1997, p. 14).

In particular, according to V.Z. Demyankov, cognitive structures oriented "in the reflection of the external structure of the world", "organized in man meaning-making" (Demyankov, 1994, pp. 24-25). With the help of the language in the scientific knowledge of a certain fixed text field of science, and the recipient using language units decodes the encrypted text in this knowledge.

Researchers believe that the polycode texts directly affect the sensory fabric of image consciousness, i.e. actualize sensory-emotive arguments along with rational (Yezhov, 2010, p. 28). As noted by G.V. Kolshanskiy, to know the world, people reflect it in their minds, language tools draw up a creative attitude of the author of the text to reality (Kolshanskiy, 1975, p. 109).

T. Miller, comparing the content of scientific documents (articles) with the scientific and popular literature, proves the importance of visual communication components of scientific documents (Miller, 1998, p. 29). As a result of the comparison carried out by them it appears that the weight and the role of non-verbal components are much higher in the actual scientific literature than in non-fiction.

The idea that the author of the text always takes into account a polycode model of the potential of the recipient can be found in the works of many scientists (Chernyshev, 2005; Lotman, 1999; Mikhalkovich, 1986; Arutyunov, 1981).

This means that a scientific text differs clearly in its communicative orientation, that is, its structure is defined by a set of the representatives of different sign systems, designed for well-defined recipient. The cognitive paradigm is generally accepted that the cognitive structures are oriented to reflect the structure of the external world.

\section{Materials and methods}

The subject of the research is Spanish texts of scientific articles and dissertations defended at the Faculty of Natural Sciences of the Autonomous University of Madrid (Spain) on various branches of knowledge, namely, chemistry, geology and geochemistry, mathematics, physics and biology in the period 2005-2015 with a total volume of 11,025 pages.

As the subject of this study act discursive mechanisms of polycodedness and specific features of the Spanish scientific discourse.

The methodological base of research is leading to modern linguistics, discursive and communicative approaches. At each stage of work involved the methods that best meet the goals and objectives of research: discourse analysis, classification and systematization of the method of quantitative analysis method, followed by a qualitative interpretation of the data.

Currently, discourse analysis is an integrated body of knowledge that deals with both oral and written text (Dijk, 1997). The text is a particular aspect of the broader concept of discourse. The concept of discourse, except for the concept of the text, includes mental processes, social and cultural context that allows the researcher by relying on this concept of an integrated approach to the study of the characteristics of generation and perception of texts from different spheres. The integrated approach is formulated in the framework of this study, due to objective necessity, as in the study of scientific texts from the perspective of linguistic theory of text-linguistics perspective the integration of text with the style of figurative means; with functional styling engaged typology of texts.

Integration with discourse theory allows us to operate with the term "text space". The text-specific space we determine the set of existing verbal and nonverbal texts that serve as a source for the generation of texts. Under text, we understand a completed in relation to the author's intention work of a speech-creative process created in the conditions of existence and the effect of text space.

In accordance with the original concept of text space for this study, a scientific text is considered an integral part of the scientific and cultural heritage, and a text space - an important text-forming component. This approach is consistent with the current trend of studying the text, allowing that the scientific text is spoken about as a dialogue with the author of the scientific text already created texts and potential, with real voice actors, and with all previous and contemporary culture. 
The method of discourse analysis has allowed that the visualization of the Spanish scientific texts is emphasized to understand and justify the concept of a hybrid of the polycodedness and semiotic substance, characterized by the phenomenon of textual heterogeneity achieved by the combination of verbal and non-verbal semiotic systems. Classification and systematization method as well as the quantitative analysis made it possible to organize the nonverbal components of the Spanish scientific text and classify the most specific to each branch of knowledge.

\section{Results and discussion}

A polycode text is presented in this study as a poly-natured fixation of mental representations of reality, perceived by the author, which then selects the manner of representation of knowledge and does so in accordance with their social and cultural experience, focusing on the level of cognitive development prepared by the recipient.

As a result, the recipient internalized scientific text, which is a representation of a fragment of reality fixed by heterogeneous sign systems.

It is important to emphasize that unlike other types of polycode texts, scientific text is model of reality, to know scientifically. Scientific text implements pronounced information function, which is revealed in the presence in it of new cognitive structures that serve to represent the new knowledge.

According to our observations, the specificity of the Spanish scientific text is that it is an integrative structural-semantic and functional unit of verbal and non-verbal elements, carrying a pragmatic orientation - to inform the recipient and to work on his mental and psycholinguistic processes.

Illustration in scientific work is an image in the form of charts, diagrams, graphics, drawing, drawings, photographs, etc., serves as a clear explanation of or in addition to any text. The thesis works, which we studied, contain various kinds of illustrations. Making each of them has its own characteristics.

Layout is most often used in the dissertations of technical profile. This is a graphic depiction of geometric forms (points, lines, surfaces, and bodies) and their aggregates performed in lines on a piece of paper. Plans designed to maximize image precision machine design, gear, equipment, devices and their components.

Scheme is an image transferred using special symbols and not to scale, the basic idea of a device, object, structure or process and showing the relationship of the main elements.

Photo is an especially convincing tool for visual validation studies. It is used when it is necessary to give a clear and detailed description of the applied research in the experimental facilities, instruments, as well as the states of individual samples of materials or elements in the different stages of this research. It is reasonable to use original photographs to illustrate theses, as a proof of the existence of some regularities in natural phenomena and in uncovering new areas of knowledge.

Each image in a dissertation is performed as part of the author's plan and shall have the proper function of informing the reader of the work done by the applicant and received results. Sometimes there is a thesis in photographs image of a man, a member of the experimental research that takes a snapshot of a documentary and convincing.

Micrography is a picture made with a microscope, widely used in the scientific studies in chemistry, physics and biology. This type of photography is irreplaceable when you need to portray with documentary precision microscopic object of study or studied phenomenon with all their individual characteristics.

Technical drawings are used in the thesis, when it is needed to represent a phenomenon or object as good as the reader perceives visually, but without unnecessary details and details. These drawings are often performed in perspective, which allows to represent the subject or object of the research in the most simple and intelligible form. Therefore, this figure is more informative and attractive to scientists than a simple circuit. With technical drawing, which is performed in a certain scale, it is possible to give a greater degree of clarity representation form reader, the structure and arrangement of the individual elements of the object. A technical drawing is especially important for understanding by a prepared reader of an opportunity to address the technical ideas of the object.

Diagram is one way of the graphic relationship between the quantities. Diagrams are drawn to visual images and are used in the analysis of large amounts of data, especially in statistics. In the analyzed dissertations, the line charts are most widely used.

Table is a kind of conditional graphic presentation.

Graphs are illustrations, in which numerical data research results are displayed by conventional image values and their relationships by geometric shapes, lines and points graphically.

A special kind of illustrative material to be used in design work in biology, geography, geology, ecology is represented by a geographic map (borrowed from other sources, or sketches). Like any other illustrative material, the representation of maps linked to the corresponding text. Usually it presented not all geographic map of a region, but only one fragment thereof, which is directly relevant to the subject under discussion.

As the studied material, different illustrations are an important component that increases the amount of information in the scientific text, and are present in varying degrees in the $100 \%$ of the analyzed texts of theses and $98 \%$ of the texts of scientific articles, as reflected in the chart. In accordance with the analysis, in the natural sciences dissertation illustrated the maximum that determines their specificity. 


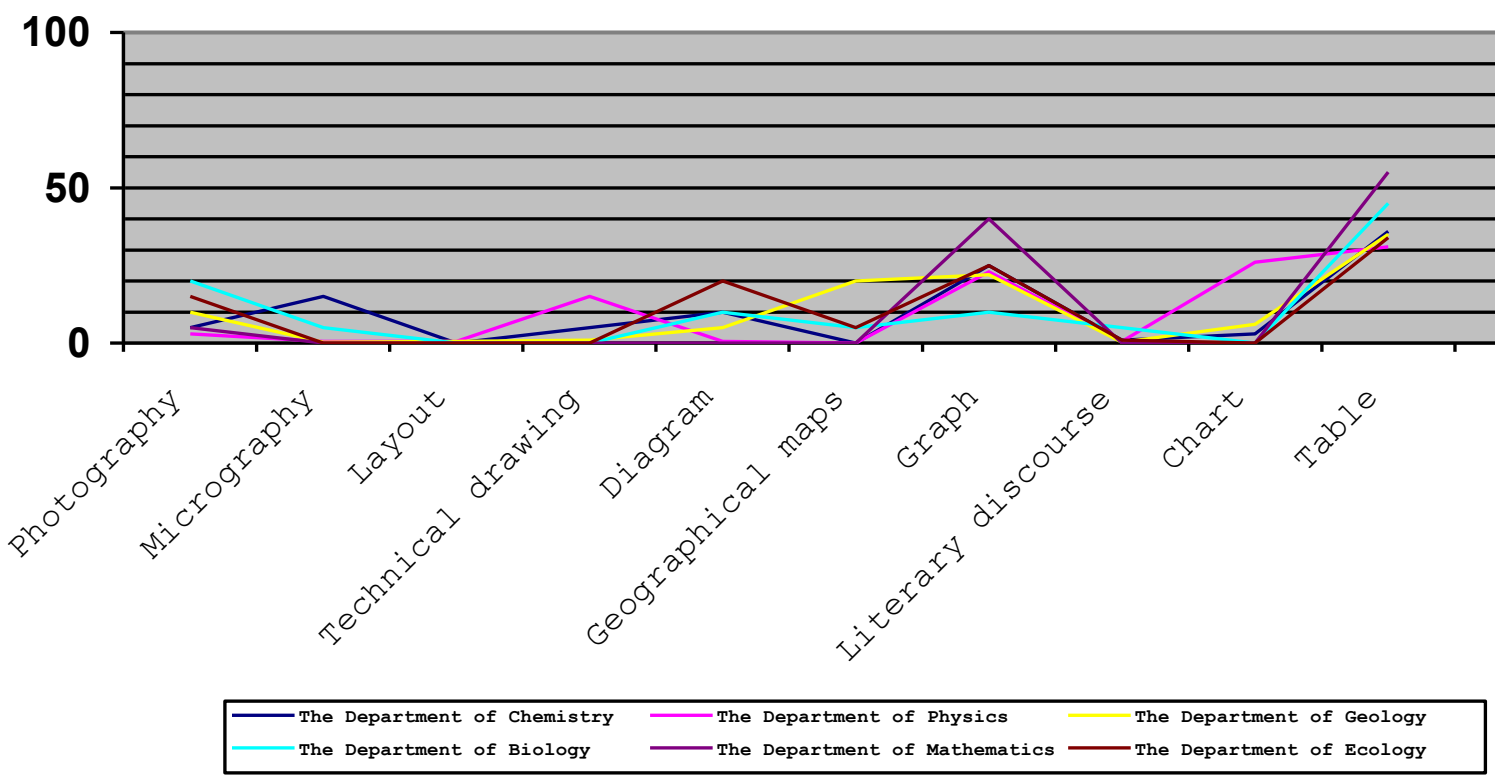

Figure 1. The frequency of using visual material in scientific papers

As it follows from Figure 1, one of the main illustrative paralinguistic means in the analyzed scientific papers are tables and graphs (25\% and 39\% of the graphic material, respectively), which allows to present the data of the study most clearly and succinctly. Due to brevity, compactness significant amount of information, autonomy and consistent form of organization of the material table fills verbal ellipse provides the visibility, clarity and expressiveness of a scientific text. In addition to the paralinguistic functions table, like any graphic image, it assumes the function of psycholinguistic and promotes the formation of a specific verbal expression.

The second highest incidence are photographs and micrographs, which enhance the reliability of the information, create a vivid impression of presence and participation of the reader in the situation described, performed communicative focus on the destination, set a dialogue with the recipient.

Photos in dissertations and scientific articles can be grouped as follows:

1. Photos (micrographies) clearly informing the recipient of the laboratory research $(10 \%)$.

2. Photos of equipment ( $8 \%)$.

3. Photos of the landscape (in the works on biology and ecology up to 95\%).

4. Photo of the author (15\%).

5. Photos of famous scientists $(1 \%)$.

In relation to the verbal phenomena, all kinds of graphic images in the scientific text perform the following functions: making additional information compactly organize the research material, replace the missing verbal component, combined with verbal means. Thus, the paralinguistic means semanticized and enter in the structural and semantic relationships within the text as a whole, condensing its semantic content; they are full-fledged components of the semiotic structure of scientific text.

The organization of the text of the dissertation and articles photos and drawings mark the main theme of the work.

The study found out that the role of non-verbal components in the actual scientific literature is very high, and research is built around visual components that are used in the proof of the solidity of the provisions put forward. The resulting extract complete and accurate information from the scientific instrument can only be based on their non-verbal (visual) components.

It is especially necessary to note the presence in scientific papers of illustrations of literary discourse that serve to explain the figurative concepts pertaining to the presentation of a scientific problem.

In the process of scientific papers analyzing texts we note a clear tendency to the aestheticization of scientific communication, which is expressed in the enhanced visualization of communicative messages, in particular the material organization of the text that is used to separate them in the common information space.

Knowledge of the world as a scientist gets in direct dialogue with the world, using a rational-logical or aesthetic ways of its development, and in dialogue with the semiotic space of culture.

As our research shows, to illustrate their thoughts the authors of the scientific text resorted to images pictured in the literary discourse. Central to take researchers a picture of the world motifs and images, objectified in literary texts and works of art of various kinds. The mention of names of biblical, mythological and literary characters indicates the intention of changing consciousness at the picture of the world created in the myths and classic works of world 
literature. This cognitive switching the author sees, apparently effective way of visual-figurative explanation of abstract concepts involved in its scientific concept.

For example, the illustrations of "Alice and the Mad Hatter at Tea" from the Lewis Carroll's "Alice in Wonderland" are integrated within the text of the thesis by Fernandez Martinez (Fernández Martínez, 2006, p. 18) with a decorative purpose, and to be more precise, with its illustrative variety - the author of scientific works is trying to attract the reader's attention, interest them in his work.

The relation of the Lewis Carroll's character to the text with a highly specialized content on the properties of mercury is obvious to the prepared recipient. Mad Hatter suffers from mercury poisoning, as hatters were forced to inhale the mercury vapor in the process of manufacture of felt and often suffered from mercury poisoning. Mercury vapors are harmful to the nervous system and cause symptoms such as muddled speech and distortion of vision.

Using the knowledge stored in the cultural memory of the author of the text ensures continuity of the scientific and educational process. It allows a scientist to find text created its place among the scientific works.

With the help of cognitive switching to other types of discourse textual actualization get stored in the cultural memory of the scientist concepts formed in the literary discourse or other discursive formations that represent the picture of the world, other than scientific.

Therefore, Elena Vallespín García (Vallespín García, 2008) in the thesis of congenital blindness pattern decorates her work by Italian artist Federico Barocci "Santa Lucia" - an early Christian saint and martyr, patron saint of the blind.

It is obvious that the author used these pictures of the world primarily in the pragmatic purposes of illustrating or explaining figuratively his thoughts to the reader as well as of rendering the message.

\section{Conclusion}

In scientific communication, a natural language is the most important and most versatile, but not the only means of communication. The study shows that it is in the interaction with characters of a different nature verbal signs most successfully realize their communicative functions. Non-verbal means in scientific discourse evolved from a secondary, subordinate source component in an equivalent text, not inferior in importance to verbal row.

The recent years are characterized by the increased volume of visual information, which has a higher informationenergy capacity and wider pragmatic potential than verbal information. Visual information, impact on individuals, is becoming more widespread, breaking the monopoly of the printed text on the transfer of information.

A polycode text captures the interaction of different codes - systems of symbols, symbols, signs, rules of their combination with each other for the transmission, processing and storage of information in the most adapted to this form.

A polycode text describes the phenomenon of textual heterogeneity at the level of form as a result of the interaction of different semiotic systems. In this sense, the phenomenon is directly related to the manifestations of polycodedness and interdiscursiveness, the interaction of different discourses. The cognitive approach helps to identify the essential properties of scientific text, remaining unnoticed when considered in the framework of other scientific paradigms. This means that it is within the cognitive approach scientific text may be viewed as a heterogeneous cognitive framework to represent, store and process information.

According to our observations, the specificity of the natural science of the Spanish text is that it is an integrative structural-semantic and functional unit of verbal and non-verbal elements, carrying a pragmatic orientation - to inform the recipient and to work on his mental and psycholinguistic processes.

In scientific texts, especially the natural sciences, it has a number of iconic cognitive functions. This is an element of text, without which the text loses its informative nature, i.e., ultimately its textuality.

For example, in the physical and mathematical, chemical texts, the texts devoted to technical development, formula, symbolic images, graphics, tables, engineering designs, geometric shapes and other visual elements are semantic components of text, transmitting the basic content of the text. Moreover, the verbal text in such cases becomes a binder and misleading link is a kind of frame.

In speech communication, a polycode text appears in difficult mathematical text forms, in which the verbal and iconic statement form one visual, structural, semantic and functional unit provides comprehensive pragmatic effect on the recipient.

Thus, the word and the image are two equal sign, the combination of which led to the emergence of the so-called "polycode texts".

A prerequisite for their creation is the nature of human perception and the fact that our civilization is focused on the visual image. Examples of polycode texts in our material are both scientific articles and dissertations. In natural science texts found great cohesion, fusion of polycode components between verbal and iconic components installed semantic relationships. A verbal text is completely dependent on a number of the fine, both the image and acts as an obligatory element of the text.

The iconic natural-science component of the text presented in the Spanish scientific discourse tables, graphs, micrographs, photographs, technical drawings, diagrams, charts, symbolic images, formulas, maps. 
Presenting information in tables and graphs, it can be concluded that the original systematization, classification of data is one of the methods to which the authors are often used in an effort to increase the efficiency of the perception of the reader of the information provided. As a clear and illustrative, advantageous polycode texts show and the information itself, and presents it to the researcher.

The reason for the use of visualization in science is an increase in reported data. The data sets now contain hundreds of millions of values. The development of computer technology has decided to question the processing of such amount of information. However, there was a problem to visualize the results of this processing. In this case, the different imaging methods by which you can easily submit large and complex data volumes. Charts and diagrams simplify and facilitate the perception of the human perception of the text. Sometimes several schemes enough to understand the meaning contained in several pages of the project.

It can be noted that the multi-dimensional view of the text as a polycode education is the result of reflection and a polycode nature of human communication.

The aestheticization of communication should be called as its obvious tendency manifested in enhanced visualization of the communicative message.

We consider the inclusion of images of literary discourse as a phenomenon cognitive shift the consciousness of the author on the picture of the world created in the myths and classic works of world culture. This cognitive switching the author sees, apparently effective way of visual-figurative explanation of abstract concepts involved in its scientific concept. It also says that between the "new" create text and other common text space exists, which incorporates all the cultural and historical experience of the individual.

The aim of the author of the scientific text is not only the expression of their ideas on paper, and report them to the reader. Should be given and the text content and form.

It is obvious that we analyzed scientific texts in recent years (2005-2015) is a great variety of fine material that confirms the image of coexistence and the verbal sign in the semiotic continuum, i.e. symptomatology image coexists with the semiology of linguistic signs. The picture is a sign of non-verbal and verbal signs come in coherent communication to build an integrative sense of the whole.

Science Spanish text is an example of semiotically complicated text, which we have considered, as a kind of a polycode text because it combines components belonging to different iconic structures - the verbal and iconic.

Verbal and visual components are connected to the substantive, meaningful, compositional, and content-language level.

The preference of a particular type of communication is determined by the communicative and task functionality of a polycode text as a whole.

Further research of the polycode texts of great interest, since such texts potentially capable of transmitting large amounts of information in a fairly compact form, thereby increasing, the information capacity of scientific papers. Presenting the information codes of different semiotic systems of polycode texts also provide a comprehensive communicative pragmatic impact on the reader, the reader draw additional attention to the information encoded by different codes, it stimulates cognitive activity.

\section{References}

Anisimova, E.E. (2003). Lingvistika teksta i mezhkul'turnaya kommunikatsiya (na materiale kreolizovannykh tekstov): Uchebnoe posobie dlya studentov fak. inostr. yaz.vuzov [Text Linguistics and Intercultural Communication (on Creolized Texts): Study Manual for Students of the University Faculties of Foreign Languages]. Moscow: Akademiya.

Arutyunova, N.D. (1981). Faktor adresata [Destination Factor]. Izvestiya AN SSSR. Seriya literatury i yazyka, 40(4), $356-367$.

Baranov, A.N., \& Dobrovolsky, D.O. (1997). Postulaty kognitivnoy semantiki [The Postulates of Cognitive Semantics]. Izvestiya AN SSSR. Seriya literatury i yazyka, 56(1), 14.

Bernatskaya, A.A. (2000). K probleme "kreolizatsii" teksta: istoriya i sovremennoe sostoyanie [On the Problem of Text "Creolization": The History and Current State]. Rechevoe obshchenie: Spetsializirovannyy vestnik, 3(11), 104-110.

Bolshiyanova, L.M. (1987). Vneshnyaya organizatsiya gazetnogo teksta polikodovogo kharaktera [External Organization of Newspaper Texts of a Polycode Nature]. In Tipy kommunikatsii i soderzhatel'nyy aspekt yazyka: Sbornik nauchnykh trudov [Types of Communication and Content Aspect of Language: Collection of Scientific Papers] Moscow: Institut yazykoznaniya AN SSSR, pp. 167-172.

Bychkov, S.S. (2013). Polikodovost' kak makrostrukturnyy priznak pechatnykh tekstov rannego novogo vremeni [Polycodedness as a Macro-Sign of Printed Texts of the Early Modern Period]. Vestnik Volgogradskogo gosudarstvennogo universiteta. Seriya 2: Yazykoznanie, 2(18), 148-153.

Voroshilova, M.B. (2007). Kreolizovannyy tekst v politicheskom diskurse [Creolized Text in Political Discourse]. Politicheskaya lingvistika, 3(23), 73-78. 
Dijk, T.A. van. (1994). Printsipy kriticheskogo analiza diskursa [Principles of Critical Discourse Analysis]. In T.A. van Dijk (Trans.), Perevod i lingvistika teksta: sbornik statey [Translation and Text Linguistics: Collection of Articles], Moscow: VTsP, pp. 169-217.

Demyankov, V.Z. (1994). Kognitivnaya lingvistika kak raznovidnost' interpretiruyushchego podkhoda [Cognitive Linguistics as a Kind of Interpretive Approach]. Voprosy yazykoznaniya, 4, 24-25.

Ezhova, E.N. (2010). Media-reklamnaya kartina mira: struktura, semiotika, kanaly translyatsii : avtoreferat diss. doktora filologicheskikh nauk [Media and Advertising Picture of the World: The Structure, Semiotics, Broadcast Channels (Abstract of the Thesis for the degree of Doctor of Philological Sciences)]. Stavropol State University. Voronezh.

Kolshanskiy, G.V. (1975). Sootnoshenie sub"ektivnykh i ob"ektivnykh faktorov v yazyke [The Ratio of Subjective and Objective Factors in the Language]. Moscow: Nauka.

Lotman, Y.M. (1999). Vnutri mysljashhih mirov. Chelovek-tekst-semiosfera-istorija [Inside Minded Worlds. Man-TextSemiosphere-History]. Moscow: Shkola "Jazyki russkoj kul'tury".

Mikhalkovich, V.I. (1986). Izobrazitel'nyj jazyk sredstv massovoj kommunikacii: Monografija [Visual Language of Mass Communication: Monograph. Moscow: Nauka, 1986.

Stepanjuk, N.V. (2004). Sposoby integracii inokodovyh soobshhenij v tekst (na materiale nauchnoj i hudozhestvennoj prozy): Diss. kandidata filologicheskih nauk [Way to Integrate Differently Coded Messages into the Text (Based on Science and Fiction) (Thesis for the degree of Doctor of Philological Sciences)]. Odessa National University named after II Mechnikov, Odessa.

Sonin, A.G. (2005). Ponimanie polikodovyh tekstov: kognitivnyj aspekt: Monografija [Understanding the Cognitive Aspect of Polycode Texts. Monograph]. Moscow: Linguistics Institute of RAS.

Chernysheva, T.V. (2005). Teksty SMI v mental'no-jazykovom prostranstve sovremennoj Rossii: Diss. kandidata filologicheskih nauk [Media Texts in Mental-Linguistic Space of Modern Russia (Thesis for the degree of Doctor of Philological Sciences)]. Altai State University. Barnaul.

Sorokin, Yu.A., \&Tarasov, E.F. (1990). Kreolizovannye teksty i ih kommunikativnaja funkcija [Creolized Texts and Their Communicative Function]. In Optimizacija rechevogo vozdejstvija [Optimization of Speech Influence]. Moscow: Nauka, pp. 180-186.

Chernyavskaya, V.E. (2009). Lingvistika teksta. Polikodovost'. Intertekstual'nost'. Interdiskursivnost' [Text Linguistics. Polycodedness. Intertextuality. Interdiscursiveness]. Moscow: LIBROKOM.

Chernyavskaya, V.E. (2016). Tekst v medial'nom prostranstve [Text in the Medial Space]. Moscow: LENAND.

Dijk, T.A. van. (1997). The Study of Discourse. In T.A. van Dijk (Ed.), Discourse as Structure and Process. Discourse Studies: A Multidisciplinary Introduction. London, Thousand Oaks, New Delhi: SAGE Publications, Vol. 1, pp. 1-34.

Dijk, T. A. van. (2000). Ideology and Discourse. A Multidisciplinary Introduction. [Online] Available from http://www.discourses.org/ (June 23, 2016).

Miller, T. (1998). Visual Persuasion: A Comparison of Visuals in Academic Texts and the Popular Press. English for Specific Purposes, 17(1), 29-46.

Fernández Martínez, R. (2006). Desarrollo y aplicación de nuevas metodologías para el estudio del fraccionamiento y movilidad del mercurio en muestras medioambientales: Tesis doctoral. Universidad Autónoma de Madrid, Facultad de Ciencias, Departamento de química. Madrid.

Vallespín García, E. (2008). Amaurosis Congénita de Leber y Retinosis Pigmentaria de Inicio Precoz: estudio clínico y genético: Tesis doctoral. Universidad Autónoma de Madrid, Facultad de Ciencias, Departamento de Biología. Madrid. 